\title{
No Battle Is Ever Won For Good
}

\section{Paulina Wawrzynczyk*}

Address

*Correspondence: p.wawrzynczyk@gmail.com

Since the Black Monday in October 2016, Polish women have been in the spotlight. The scale of this strike amazed not only feminists all around the world but also Polish activists used to much smaller public protests. What had to happen to provoke such a massive reaction and what has happened since?

Firstly, let's take a look at the history of the law regarding abortion in Poland. Not surprisingly, during different authoritarian or totalitarian regimes abortion was fully or almost illegal. The law changed in 1956 on the wave of a political thaw after the death of Stalin. As a result, abortion due to 'difficult living conditions' became widely available on demand.

(c) Copyright: The Authors. This article is issued under the terms of the Creative Commons Attribution NonCommercial Share Alike License, which permits use and redistribution of the work provided that the original author and source are credited, the work is not used for commercial purposes and that any derivative works are made available under the same license terms.
Because of non-existent or limited access to contraception, it was a popular and widely accepted procedure.

Shockingly, after peaceful and democratic transformation of our society with the fall of communism in 1989, conservative politicians immediately undertook attempts to limit unrestricted access to abortion. After massive campaigns and huge counter-protests a new bill was introduced and remains in force. According to it, abortion is legal in three cases: when woman's life or health are in danger, the foetus is seriously malformed or when the pregnancy is a result of a crime. What has to be highlighted is that not many countries have gone down this path from legalisation to tightening up abortion regulations. The Polish nation has gained freedom, yet reproductive freedom has been taken away from women straight away. The Hierarchy of the Catholic Church was one of the most significant decision-makers in this process. Conservative politicians agreed on so called 'abortion compromise' (a compromise only with the 
Church which would like to ban it completely) and have changed the public debate about abortion for years.

Although the same bill introduced compulsory sex and relationships education (SRE) to Polish schools and obliged the authorities to provide access to contraceptives, these elements remain on paper. We can argue if the lack of SRE would have been more beneficial than a biased version of it - through all these years and regardless of the ruling party, the Polish Ministry of National Education has supported only the Catholic approach to educating about sexuality. Beliefs-based information presented in school books could not have been further from the up-to-date scientific research. Teachers, school headmasters and parents have not been encouraged to pay attention to the quality and curricula of SRE lessons. What is worth mentioning is that promoting abstinence-only programmes is counterproductive to the idea of decreasing the number of unintended pregnancies, it only results in less safe sex.

Both at schools and in the media, the narrative about abortion has changed drastically and anti-choice rhetoric has dominated all debates. The battle over the language has been lost and terms like 'a conceived child' or 'killing babies' have switched focus from women who get pregnant to embryos. The educational role of the law proved to be working - the word 'abortion' has become a taboo and the Polish society has got quickly used to the situation when it is sought either in the underground or abroad. Both of these options are expensive and leave disadvantaged women in danger. In reality, since physicians have the right to plead conscience clause, legal abortion is also impossible to obtain in many Polish hospitals. The lack of access to free and safe abortion seems to suit health care providers who are either too intimidated or well paid in the underground to stand up with women. I am sorry to say this - despite the obvious violations of human rights, overall this system has so far been comfortable enough to not to cause mass protests. Feminist organisations which constantly fight to change it have been left alone and underfunded for years. 
The older generations have quickly forgotten how abortion was widespread in the past, young people have followed the Catholic propaganda and become more compassionate for foetuses than women. This has not only diminished the efforts to bring back our rights but also encouraged religious fanatics to proceed with banning abortion completely and punishing women who have had one. In 2016, after the first year of the single-party ruling of the far-right PiS, another project like this was forwarded in the Polish parliament. Nonetheless, this time it was too much to bear, 'the compromise' was endangered and the remaining rights could have been taken away. In response, women gathered spontaneously and protested in many places in Poland on a scale that has not been seen before. It scared the parliamentarians and they rejected the bill.

As successful as it may seem, showing our power and rage has not stopped PiS from continuously humiliating Polish women. After cutting off funds for a NGO supporting survivors of gender-based violence and declaring the will to withdraw from the Istanbul Convention (signed and ratified after enormous battles) I am not hopeful about the near future. Nevertheless, what is promising is growing awareness of Polish citizens who started to notice injustice and hypocrisy in which we live, and to discuss reproductive rights. The threat of losing everything and putting women in a real danger was a wake-up call. The word 'abortion' has regained its place in debates. Women who protested together have stayed in touch and do not stop mobilising themselves and their communities.

The Polish case exemplifies how far-right movements value women's wellbeing, health and lives. In any country no rights are won for good. We must pay attention to mechanisms that take place all around the world and continue to raise awareness of what we have fought for and what may be taken away from us. I believe that only global solidarity and mass protests will lead us to reproductive freedom for all. 
Paulina Wawrzynczyk is a sex and relationships educator, social and political activist, women's and girl's rights advocate, author and speaker. Born in Warsaw, lives in London.

\section{To cite this article:}

Wawrzynczyk, P. (2017). No Battle Is Ever Won For Good. Feminist Dissent, (2), 189-192. Retrieved from:

http://journals.warwick.ac.uk/index.php/feministdissent/article/view/16/91 